\title{
PPARs in Regulation of Paraoxonases: Control of Oxidative Stress and Inflammation Pathways
}

\author{
Jordi Camps, Anabel García-Heredia, Anna Rull, Carlos Alonso-Villaverde, Gerard Aragonès, \\ Raúl Beltrán-Debón, Esther Rodríguez-Gallego, and Jorge Joven
}

Centre de Recerca Biomèdica, Hospital Universitari de Sant Joan, Institut d'Investigació Sanitària Pere Virgili, Universitat Rovira i Virgili, 43201 Reus, Spain

Correspondence should be addressed to Jordi Camps, jcamps@grupsagessa.com

Received 26 July 2011; Accepted 17 October 2011

Academic Editor: J. Reddy

Copyright ( $\odot 2012$ Jordi Camps et al. This is an open access article distributed under the Creative Commons Attribution License, which permits unrestricted use, distribution, and reproduction in any medium, provided the original work is properly cited.

\begin{abstract}
The paraoxonase (PON) group of enzymes, composed of PON1, PON2, and PON3, play an important role in decreasing oxidative stress by degrading lipid peroxides. PON1 synthesis is upregulated by PPAR. Several pharmacological compounds (acting as antioxidants and, hence, atheroprotective) stimulate both PPAR activity and PON1 expression. Recent evidence suggests that PON1 and the monocyte chemoattractant protein-1 (MCP-1) are involved in coordinating the inflammatory response in damaged tissues; PPAR may be central in the regulation of these biochemical pathways. This article reviews the state of knowledge on PON1 biochemistry and function, the influence of genetic variation, and the regulation of PON1 expression by pharmaceutical compounds that increase PPAR activity. We also describe recent lines of evidence suggesting links between PON1 and MCP-1 and how their production may be regulated by PPAR.
\end{abstract}

\section{Introduction}

Nuclear receptors are a large group of transcription factors which are important as master regulators of genes involved in metabolic control. Hence, an intensive search for ligands for these receptors is underway so as to design improved preventive and therapeutic strategies that target these ligands/receptors in an effort to combat diseases which are direct determinants of the human lifespan. Among these receptors are the peroxisome proliferator-activated receptors (PPARs). The name is confusing because they do not induce proliferation of peroxisomes in humans, but which has been described in rodents [1]. When this receptor was cloned, it was termed PPAR $\alpha$ [2]. PPAR $\beta / \delta$ and $\gamma$ were identified subsequently as structural homologues of $\operatorname{PPAR} \alpha$, which were shown to control the expression of other metabolic genes. The PPAR subfamily of nuclear receptors all bind as heterodimers with RXR to peroxisome proliferator response elements in the target gene, especially those involved in the homeostatic control of metabolism and in the defense against toxic compounds. Of particular importance is the association of these receptors with the risk of cancer, cardiovascular diseases, diabetes and dementia, as well as inflammation and oxidative stress responses that underlie these diseases. In this scenario, it is relevant to review the relationships between PPAR and the antioxidant enzymes collectively termed paraoxonases (PONs).

\section{The Paraoxonases and Lipid Peroxide Degradation}

The PON protein family comprises 3 enzymes, PON1, $\mathrm{PON} 2$, and PON3 genes coding which are located close to each other on chromosome 7q21-22 [3, 4]. PON1 and PON3 genes are expressed in most tissues, and their protein products are found in circulation bound to highdensity lipoprotein (HDL) [5-7]. Conversely, PON2 is an intracellular enzyme which is not found in plasma [8]. PON1 was first identified by Aldridge in 1953 who, while examining the rates of hydrolysis of organophosphate insecticides in different tissues of rats and rabbits $[9,10]$, observed that rabbits had a very high rate of paraoxon degradation in serum, and that this compound was cleaved by an esterase. 

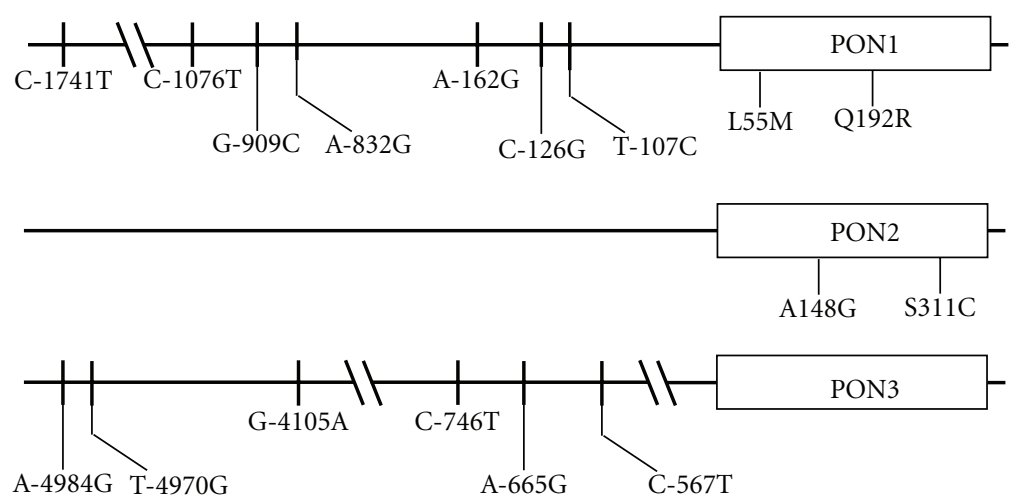

FIgURE 1: Schematic representation of the most prevalent polymorphisms of the PON1, PON2, and PON3 genes.

Aldridge segregated esterases into two categories according to whether they were inhibited by interaction with substrates (B-esterases) or whether they could hydrolyze substrates (Aesterases). Based on these original publications, the serum A-esterase was referred to as paraoxonase because of its ability to hydrolyze the toxic oxon metabolite of parathion, hence "paraoxon". When two closely similar enzymes were identified in the mid-1990s, the original paraoxonase was referred to as to PON1, while the two new enzymes were termed PON2 and PON3 [3].

The ability to hydrolyze paraoxon was employed in the 1960 s as the method to measure PON1 activity in several species and tissues. It soon became apparent that, in human serum, there was considerable variability between individuals with respect to PON1 activity. Frequency distribution histograms found three different phenotypes, corresponding to high, intermediate, and low serum PON1 activities. Also, the frequency for the low activity allele varied significantly between populations of different geographical or ethnic origin, a higher frequency being observed in Caucasian than in African, Asian, or Australian aborigine populations [11].

Over subsequent years, several assays were developed to examine the PON1 phenotype polymorphism [12]. Plotting the values of hydrolysis of one substrate (whether phenyl acetate, diazoxon, or sarin) against that of a second substrate (paraoxon) provided a clear resolution of the individuals with low (termed $\mathrm{AA}$ ), intermediate (termed $\mathrm{AB}$ ), and high (termed BB) PON1 activities [13]. Eckerson et al. [14, 15] noted that the $\mathrm{B}$ isozyme was more active in the presence of $\mathrm{NaCl}$. Using this property, the authors plotted arylesterase activity values against paraoxonase activity values measured in the presence of $1 \mathrm{M} \mathrm{NaCl}$. This system was shown to be the most efficient in differentiating between different PON1 polymorphisms.

The genetic bases of PON1 phenotype polymorphisms were first defined by Adkins et al. [16] who sequenced the coding region for PON1 from human cDNA libraries and identified two polymorphic sites: Arg/Gln at position 192 $\left(P O N 1_{192}\right.$ polymorphism, with two alleles termed $\mathrm{Q}$ and $\mathrm{R})$, and Leu/Met at position $55\left(\mathrm{PON1}_{55}\right.$ polymorphism, with two alleles termed $\mathrm{L}$ and $\mathrm{M}) . P O N 1_{192}$ polymorphism correlated clearly with the $\mathrm{AB}$ phenotype system, QQ

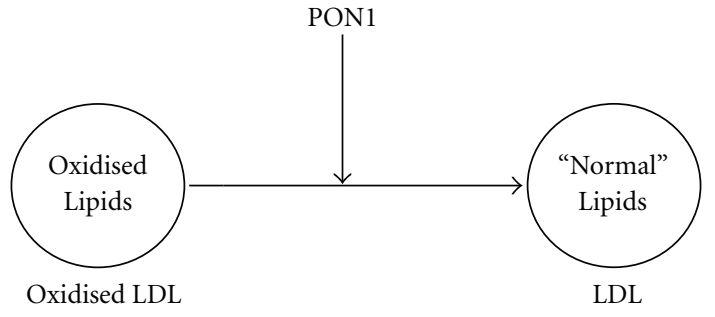

FIgure 2: The antioxidant role of PON1. The main physiological role of this enzyme is to degrade oxidized phospholipids and oxidized cholesteryl esters in lipoproteins.

individuals segregated with the AA phenotype while RR individuals segregated with the BB phenotype.

In 1997, Blatter Garin et al. [17] evaluated the influence of $P O N 1_{192}$ and $P O N 1_{55}$ polymorphisms on the enzyme's activity as well as its concentration. They observed considerable differences in relation to $P O N 1_{55}$ genotype, individuals carrying a leucine at position 44 ( $\mathrm{L}$ isoform) having higher serum PON1 concentrations than those with a methionine (M isoform) at this position. In contrast, the $P O N 1_{192}$ polymorphism affected enzymatic activity but had only a slight impact on the concentration of PON1 in serum. These findings suggested a possible divergence between the enzyme's concentration and that of its activity. More recently, several polymorphisms in the promoter region of the PON1 gene have been described (Figure 1). However, only $P O N 1_{-108}, P O N 1_{-909}$, and $P O N 1_{-1741}$ appear to be significantly associated with changes in the enzyme's concentration or activity in serum.

The first approximation to the possible physiological role of PON1 came from experiments by Mackness et al. [18]. Since paraoxon and other toxic chemicals are clearly not present in the human body under normal circumstances, other molecules would need to be the physiological substrates of this enzyme. These authors investigated, using purified PON1, the protection against copper-induced oxidation of low-density lipoprotein (LDL) that is provided by HDL (Figure 2). They observed that HDL as well as PON1 prevented lipoperoxide generation during the process of LDL oxidation. This implied that the enzyme itself 


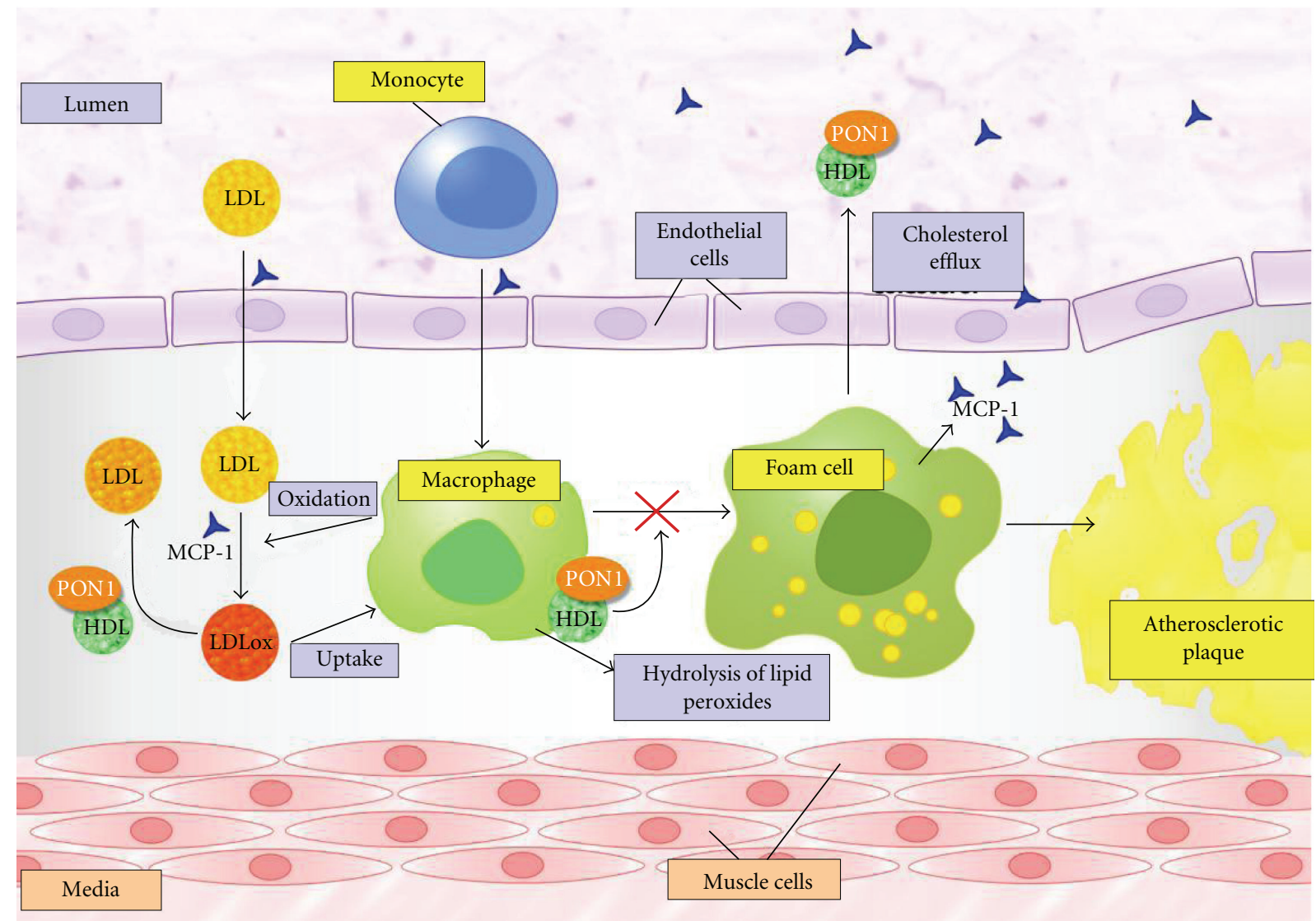

FIGURE 3: The protective role of PON1 in atherosclerosis. Circulating monocytes are activated in an oxidant and inflammatory environment and become macrophages. This environment also promotes the oxidation of LDL particles, which are internalized into the macrophages that become foam cells. PON1 hydrolyzes oxidized lipids in LDL, reversing this lipoprotein to its natural status and, thus, inhibiting the development of atherosclerosis. PON1, by inhibiting the production of MCP-1, is anti-inflammatory and favors cholesterol efflux from macrophages.

may be involved in the protective function attributed to HDL. Further studies provided evidence that PON1 protects LDL and HDL from lipid peroxidation by degrading specific oxidized cholesteryl esters and specific oxidized phospholipids contained in oxidized lipoproteins [19-25]. Experimental animal studies provided further support to the in vitro experiments, the data showing that the physiological function of PON1 is to hydrolyze oxidized lipids and, hence, function as an antioxidant enzyme. Decreased serum PON1 activities and increased oxidative stress were observed in apolipoprotein E-deficient mice as well as in dyslipidemic obese mice [26]. Perhaps the most conclusive data were generated in the PON1-deficient mouse model and the humanPON1 transgenic mouse model, PON1 plus apolipoprotein $\mathrm{E}$ double-deficient mice showing increased lipoprotein oxidation and atherosclerosis than the apolipoprotein Ealone deficient mice. HDL isolated from PON1-deficient mice was unable to prevent LDL oxidation in cultured arterial tissue, in contrast to HDL obtained from control mice. Avian HDL (the lipoprotein does not contain PON1) is unable to protect LDL from oxidation. In agreement with these observations, overexpression of human PON1 in transgenic mice inhibited lipid peroxide formation in HDL and protected LDL structure and function [27-30]. A scheme of the role played by $\mathrm{PON} 1$ in protecting against oxidative stress and atherosclerosis is shown in Figure 3.

PON1 is, in turn, inactivated by oxidized lipids. This was shown by Aviram et al. [31], who demonstrated that incubating PON1 in vitro with oxidized palmitoyl arachidonoyl phosphatidylcholine, lysophosphatidylcholine, and oxidized cholesteryl arachidonate resulted in inactivated PON1 arylesterase activity, as well as did oxidized LDL. Cysteine-284 was required for this effect of oxidized lipids on PON1 because, in recombinant PON1 in which mutation of this amino acid had been induced, no inactivation was observed. Further investigation by the same research group showed that, under oxidative stress, PON1 may be inactivated by $S$-glutathionylation, a redox regulatory mechanism characterized by the formation of a mixed disulfide between a protein thiol (i.e., cysteine-284) and oxidized glutathione [32].

\section{PON1 Native Activity Is Lactonase}

PON1 hydrolyzes a broad range of substrates including esters, lactones, organophosphates such as the nerve agents 
soman and sarin, lipid peroxides, and estrogen esters [12, 13 , $33,34]$. In addition, PON1 metabolizes certain drugs and has been proposed for therapeutic use in drug inactivation $[35,36]$. Identifying the native function of PON1 has been hampered, for a considerable time, by confusion with respect to the structure and mechanism-of-action of this enzyme. Purified PON1 preparations are unstable and often contaminated. However, the method of "directed evolution" has been productive in determining PON1 structure and function. Essentially, directed evolution seeks to replicate the evolutionary process in the laboratory by artificially inducing mutations in the gene-of-interest, followed by selection and amplification of the variants which show an enhancement of the desired characteristics. Using this technique, Harel et al. [37] described PON1 as a six-bladed beta propeller with a unique active site lid that is also involved in HDL binding. The active site and the deduced catalytic mechanism suggested that PON1 is reminiscent of the secreted phospholipase A2. Despite huge increase in complexity of living organisms during evolution, relatively little novelty has been produced at the molecular level since primordial times [38]. PONs appeared very early in evolution and are present in many organisms, from invertebrates to mammals [12]. Jensen [39] proposed that, in contrast to more evolutionary-modern enzymes, primitive enzymes possessed very broad specificities, and that it is this catalytic versatility that enabled a relatively few enzymes to perform the multitude of functions necessary to maintain the ancestral organism [40-43].

Hence, research on PON1 function was focused on trying to distinguish the native or "ancestral" function of this enzyme from all other secondary or "adapted" functions. Again, directed evolution studies, together with structurefunction studies, established the primordial function of PON1 as that of a lipolactonase [44-47] which subsequently evolved new substrate specificities. These studies also established that the preferred substrates of PON1 are 5- and 6membered-ring lactones, typically with aliphatic side-chains [38].

New data on the PON1 mechanism of lactone hydrolysis have been reported by Tavori et al. [48] using modeling and docking simulation techniques. These methods use theoretical models of the ligands being evaluated (in this case, lactones) which are allowed to interact with models of the protein's three-dimensional structure. This enables the nature of the target ligand, as well as the fitness of the evaluated ligand within the protein, to be determined. The authors suggested that PON1 active site may be reached by a range of lactones that have similar orientation in the active centre. The carboxylate moiety is directed towards the hydrophylic inner part of the active centre, while the ligand's aromatic ring is facing the outer hydrophobic part. The results from Tavori et al. also revealed an inverse correlation between docking energy and rate of lactone hydrolysis, as well as a direct correlation with the length of lactone side chain.

Recently, kinetic and site-directed mutagenesis studies demonstrated that the His ${ }^{115}$-His ${ }^{134}$ dyad is necessary for PON1 lactonase activity and, as well, for oxidized lipid
Oxidised PC products with 5-OH groups
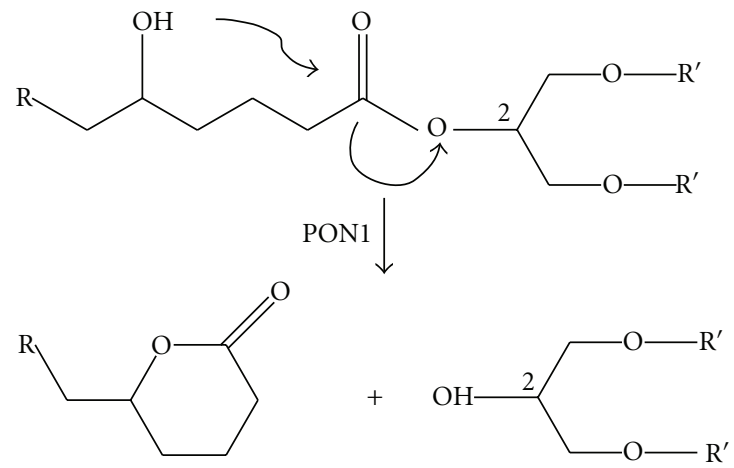

$\delta$-valerolactone derivatives

LPC

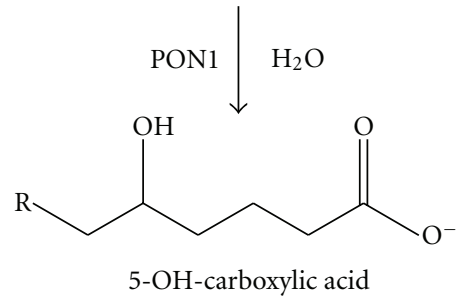

FIgURE 4: Proposed mechanism for the hydrolysis of oxidized lipids in macrophages by PON1 to yield lysophosphatidylcholine. Oxidized lipids with hydroxyl groups at the $5^{\prime}$ position could be lactonized by PON1 to yield lysophosphatidylcholine and the corresponding $\delta$-valerolactone products. The latter can be hydrolyzed again by PON1 to yield the corresponding 5-hydroxycarboxylic acid.

degradation $[49,50]$. A model has been proposed to link PON1 capability with that of lipid peroxide degradation [50]. According to this model, oxidized lipids containing hydroxyl groups at the $5^{\prime}$-position could be lactonized by PON1 to yield lysophosphatidylcholine and $\delta$-valerolactone products (Figure 4). As such, according to this hypothesis, the PON1 ability to degrade lipid peroxides is secondary to its lipolactonase activity.

\section{The Role of PON2 and PON3}

Currently, not much is known about PON2 and PON3 proteins. Their genes were identified in 1996 when Primo-Parmo et al. [3] identified a large number of cDNA sequences in the Genome Data Base with significant homology to, but not identical with, human PON1. The percentage identity among human PON1, PON2, and PON3 genes is similar (about $70 \%$ ) and the genes are believed to derive from a common precursor [51]. $\mathrm{Ng}$ et al. [8] demonstrated that PON2 is not present in the circulation, although its gene expression was detected in several human tissues. The authors concluded that this represents ubiquitous intracellular distribution of the enzyme. They also reported that cells transfected with the human PON2 gene have a higher antioxidant capacity than those cells that were not transfected. PON3 is present in HDL and prevents lipoproteins from oxidation in vitro. PON2 and PON3 also have genetic polymorphisms in their 
Table 1: Principal properties of the PON enzymes.

\begin{tabular}{lcccccc}
\hline Enzyme & Gene expression & Protein expression & $\begin{array}{c}\text { Present in } \\
\text { circulation }\end{array}$ & Lactonase activity & $\begin{array}{c}\text { Hydrolysis of } \\
\text { lipid peroxides }\end{array}$ & Esterase activity \\
\hline PON1 & Ubiquitous & Ubiquitous strong & HDL & Yes & Yes & Yes \\
PON2 & Ubiquitous & Ubiquitous weak & No & Yes & Yes & No \\
PON3 & Ubiquitous & Ubiquitous strong & HDL & Yes & Yes & No \\
\hline
\end{tabular}

promoter and codifying regions that influence their protein expression (Figure 1). Both PON2 and PON3 are able to hydrolyze lactones, but not paraoxon or other xenobiotics $[34,52,53]$, that is, all three PON enzymes have lactonase activity and hydrolyze lipid peroxides, but only PON1 has esterase activity (Table 1).

\section{PON1 and PPAR $\alpha$}

Fibrates are hypolipidemic drugs that act via activation of PPAR $\alpha$. Their main therapeutic function is to decrease serum triglyceride concentrations. A mild increase in HDLcholesterol concentration is also achieved. PPAR $\alpha$ activators induce the expression of apolipoprotein A1, the main apoprotein of HDL, and of the ATP-binding cassette of A1 (ABCA1), a transporter complex controlling cellular cholesterol efflux [54].

There have been conflicting reports on the influence of fibrate therapy on serum PON1 levels. Increase in enzyme activity appears to depend on type, and perhaps dosage, of fibrate employed. Durrington et al. [55] observed that bezafibrate and gemfibrozil, administered for 8 weeks, failed to influence serum PON1 activity in type IIb hyperlipidemic patients. Tsimihodimos et al. [56] found that 3-month treatment with micronized fenofibrate did not influence PON1 levels in types IIa, IIb and IV dyslipidemic patients. Conversely, Paragh et al. [57] observed that a 3-month administration of gemfibrozil increased serum PON1 activity in patients with hypertriglyceridemia. This research group found that ciprofibrate administration increased HDLcholesterol concentration and serum PON1 activity in patients with metabolic syndrome [58]. In rats receiving a fructose-enriched diet (an experimental model of liver steatosis and metabolic syndrome), bezafibrate reduced oxidative stress and increased serum PON1 levels [59]. A recent report described that micronized fibrate increased the activity and concentration of PON1 and reduced oxidized LDL levels in dyslipidemic patients with low HDLcholesterol levels. Interestingly, this effect was independent of $P O N 1$ gene polymorphisms [60]. There are several potential PPAR $\alpha$ binding sites in the PON1 gene promoter. However, Gouédard et al. [61] did not observe any increase in PON1 gene expression following PPAR $\alpha$ activation, and this suggested that the mechanism of promoter activation induced by fibrates does not involve this nuclear receptor.

\section{PON1, PON2, and PPAR $\gamma$}

Rosiglitazone is a PPAR $y$ agonist that improves insulin sensitivity and glycemic control, stimulates reverse cholesterol transport, and reduces inflammation in individuals with type 2 diabetes [62-64]. In a randomized, cross-over, placebo-controlled, double-blind clinical trial, rosiglitazone was shown to increase fasting PON1 activity and to attenuate the postprandial fall in PON1 activity. However, the concentration of serum PON1 was observed not to change significantly [65]. A combination of rosiglitazone and metformin improved insulin resistance and fat distribution abnormalities (lipodystrophy) in patients infected with the human immunodeficiency virus (HIV) [66]. Our group reported that both treatments increased fasting and post-prandial serum PON1 activity and decreased plasma concentrations of the monocyte chemoattractant protein-1 (MCP-1) in HIV-infected patients undergoing highly active antiretroviral therapy [67]. Results from these studies indicated that plasma HDL-cholesterol concentrations did not significantly change. These data suggested that the observed effects on PON1 were independent of HDL synthesis. We also reported that metformin activates the peroxisome proliferators-activated response coactivator- $1 \alpha$ and regulates oxidative stress homeostasis [68].

Several studies have shown that statins, widely used pharmacological compounds for the treatment of hyperlipidemia, activate PPAR $\gamma$, and that this activation is associated with increases in PON1 expression. Tomàs et al. [69] were the first to report that simvastatin administration $(20 \mathrm{mg} /$ day for 4 months) increased serum PON1 activity in hypercholesterolemic patients. The increases were modest (about $12 \%$ on average) and were accompanied by significant decreases in serum cholesterol and lipid peroxides, as well as LDL-cholesterol concentrations. They did not find any significant modulation associated with HDL-cholesterol levels or with $P O N 1_{192}$ and $P O N 1_{55} D N A$ polymorphisms. Simvastatin attenuated myocardial inflammation in rats that had cardiopulmonary bypass surgery, and the phenomenon was associated with an increase in PPAR $y$ expression [70]. Atorvastatin and rosuvastatin have also been shown to increase PPAR $\gamma$ [71] and PON1 expressions. Harangi et al. [72] observed that atorvastatin ( $10 \mathrm{mg} /$ day for 6 months) increased serum PON1 activity in hypercholesterolemic patients, with changes in lipid profile and oxidative stress similar to those described by Tomàs et al. (described above). Kassai et al. [73] also confirmed that atorvastatin ( $20 \mathrm{mg} /$ day for 3 months) increased serum PON1 activity. This statin has been shown to increase serum PON1 activities in experimental rabbits fed a high-cholesterol diet [74]. However, Bergheanu et al. [75] reported that atorvastatin (increasing doses up to $80 \mathrm{mg} /$ day for 18 weeks) did not modify serum PON1 activity, although rosuvastatin administration (increasing doses up to $40 \mathrm{mg}$ /day for the same 


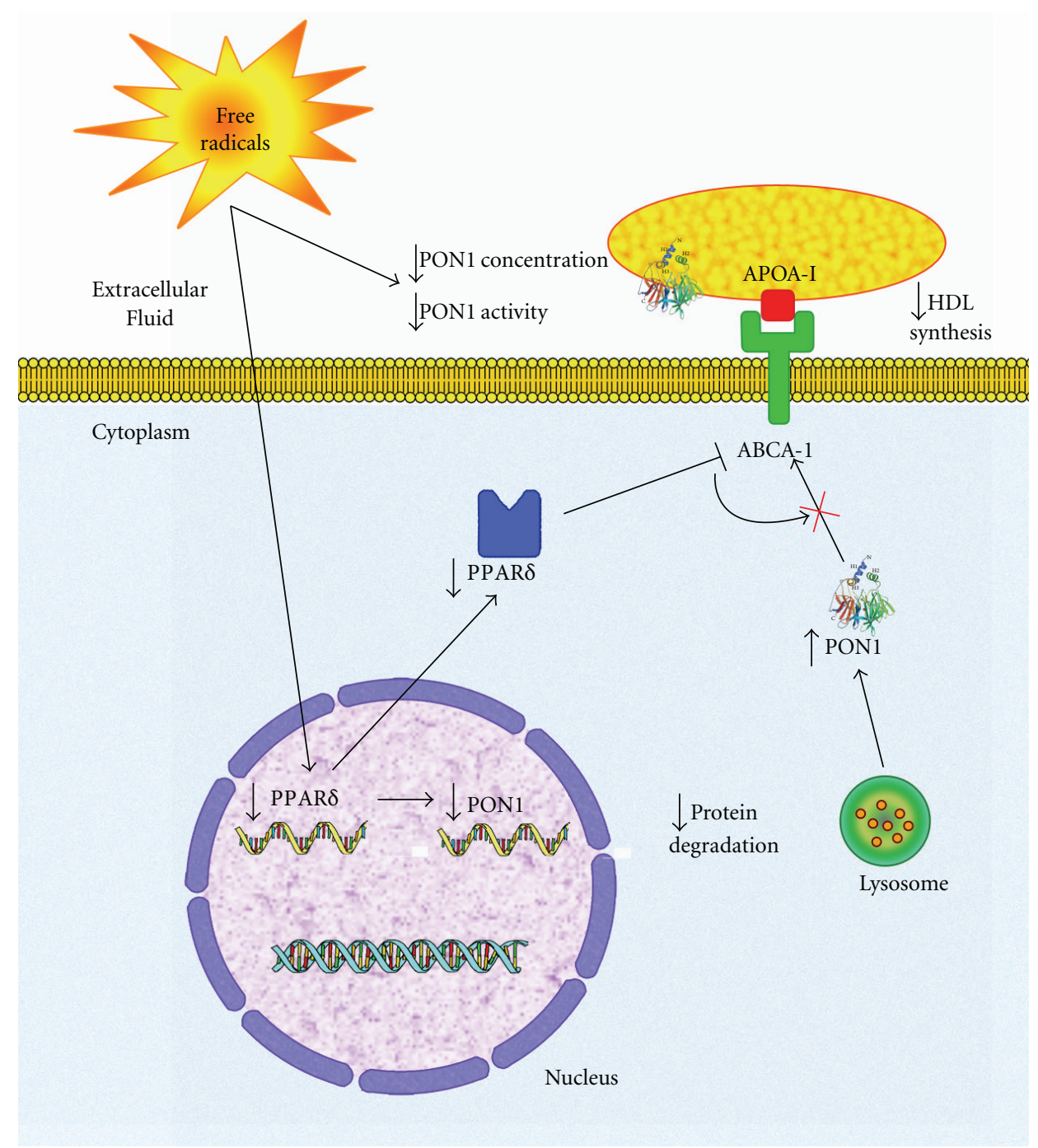

FIgURE 5: A hypothetical biochemical pathway that could explain the PON1 alterations observed in rats with experimental cirrhosis. Freeradical-induced liver impairment would result in a decrease in PPAR $\delta$ gene expression and, as a consequence, in PON1 gene expression. It would also induce an inhibition of ABCA1, a decrease in HDL synthesis, and, therefore, a decrease in serum PON1 concentration. Intrahepatic PON1 levels would be increased as a consequence of decreased protein degradation. This figure is reproduced from [79].

period of time) was associated with a significant increase in serum PON1 activity. A recent detailed clinical report by Mirdamadi et al. [76] was that of a study conducted with 164 hypercholesterolemic patients subdivided into three groups to receive atorvastatin $(10 \mathrm{mg} / \mathrm{day}, n=61)$, simvastatin $(10$ $20 \mathrm{mg} /$ day, $n=46)$, or fluvastatin $(80 \mathrm{mg} /$ day, $n=57)$ for a period of 3 months. The results indicated that all three statins were able to increase serum PON1 activity, albeit moderately.

Of note is the study by Shiner et al. [77] which found that antioxidant polyphenols obtained from some plants increased PON1 and PON2 expression through PPAR $y$ activation. Pomegranate juice and its polyphenols (punicalagin and gallic acid) increased PON2 expression in cultured macrophages, and this phenomenon was associated with activation of PPAR $y$ and AP-1. Similarly, the incubation of hepatocytes with polyphenols from pomegranate juice increased PON1 expression via the PPAR $\gamma$-PKA-cAMP pathway [78].

\section{PON1 and PPAR $\delta$}

There is a dearth of information on the possible relationships between PPAR $\delta$ and PON1. Our group reported [79] that rats with experimental liver cirrhosis had a significant decrease in hepatic PPAR $\delta$ and PON1 expression which was associated with inflammatory and fibrogenetic reactions. However, hepatic PON1 protein concentration was increased as a consequence of a decreased degradation of the enzyme (Figure 5). We did not observe any significant change in PPAR $\alpha$ and PPAR $\gamma$ expression. These results suggested an involvement of PPAR $\delta$ in the regulation of oxidative stress in chronic liver impairment. To the best of our knowledge, this 
is the only published report showing an association between this transcription factor and PON1.

\section{Combined Functioning of PON1 and MCP-1 in Regulating Inflammatory Response: A Role for PPAR?}

The upregulation of MCP-1 production by oxidized lipids and lipoproteins is an important factor in the initial stages of inflammation [80, 81]. Mackness et al. [82] demonstrated that PON1, when incubated with endothelial cells, inhibited the production of MCP-1 induced by oxidized LDL. Indeed, several lines of evidence recently published by our group suggest that PON1 and MCP-1 act collaboratively in regulating inflammatory processes. PON1 and $\mathrm{MCP}-1$ protein expressions are observed in conjunction in most normal and diseased tissues, while increased MCP-1 concentration and decreased PON1 activity are often observed in conditions involving oxidative stress $[7,83,84]$.

Lysophosphatidylcholine (LPC) is a prominent component of oxidized LDL. During oxidation, $40 \%$ of LDL phosphatidylcholine can be converted to LPC by LDL-associated phospholipase A2. LPC stimulates the cellular production of MCP-1 at the transcription level through a mechanism that involves MEK/ERK, tyrosine kinase, and (to a lesser extent) protein kinase C (PKC) [85]. More recent data suggest that 12/15-lipoxygenase $(12 / 15 \mathrm{LO})$ is required for early onset high-fat-diet-induced adipose tissue inflammation and insulin resistance in mice [86]. Cells overexpressing 12/15LO secrete an excess of MCP-1 and, correspondingly, adipose tissues from 12/15LO knockout (KO) mice fed a high-fat diet are not infiltrated by macrophages, do not show any increase in inflammatory markers, and do not exhibit changes in insulin-stimulated glucose disposal rate or of hepatic glucose output.

An interesting hypothesis is that PPARs are intimately involved in regulating and coordinating PON1 and MCP-1 expression. Considerable evidence (highlighted here in after) shows that PPARs upregulate PON1 expression in a variety of clinical and experimental situations. Recent evidence indicates that PPAR downregulates MCP-1 expression. Simvastatin decreases serum MCP-1 concentration in rats with cardiopulmonary bypass surgery and stimulates myocardial PPAR y levels [70]. Similarly, rosuvastatin and atorvastatin increases PPAR expression and attenuates atherosclerosis mice deficient in apolipoprotein E [71]. Propofol, a sedative with antioxidant properties, decreases oxidative stress and MCP-1 production and increases PPAR $\gamma$ in mice with sepsisinduced acute kidney injury [87]. Quercetin attenuates inflammation, decreases MCP-1 production, and improves insulin resistance in human-cultured adipocytes. This compound also counteracts tumor necrosis factor-induced inhibition of PPAR $y$ expression in these cells [88]. Rosiglitazone, which is a ligand for PPAR $\gamma$, inhibits inflammation and reduces MCP-1 production by murine cells [89] and has similar effects on lipopolysaccharide-treated mice and HK-2 cells [90]. Finally, telmisartan, an angiotensin type I receptor blocker, increases PPAR $\gamma$ activity and PPAR ligand-binding activity, reduces atherosclerosis in mouse macrophages [91], and reduces MCP-1 production by peripheral monocytes in patients with essential hypertension [92].

\section{Conclusion}

It seems well established that PPARs, especially $\operatorname{PPAR} \gamma$, are important factors in the regulation of PON1 expression, and in counteracting oxidative stress. Evidence exists that they also contribute to the control of inflammation by downregulating the expression of MCP-1. Several pharmaceutical preparations eliciting a beneficial antioxidant, antiinflammatory, and atheroprotective function increase PON1 expression and decrease that of MCP-1. These data suggest that PPARs play a key role in the regulation of oxidation and inflammation and, as such, drugs that stimulate PPAR activity may be important tools in the struggle against diseases related to these biochemical alterations.

\section{Acknowledgments}

Some studies described in this article have been funded by Grants from the Instituto de Salud Carlos III (PI 02/0430, PI 04/1752, PI 05/1607, PI 08/1175, PI 08/1381, RCMN C03/08, and RD06), Ministerio de Sanidad, Madrid, Spain. Editorial assistance was provided by Dr. Peter R. Turner from $t$-SciMed (L'Ametlla de Mar, Spain).

\section{References}

[1] J. M. Thorp and W. S. Waring, "Modification of metabolism and distribution of lipids by ethyl chlorophenoxyisobutyrate," Nature, vol. 194, no. 4832, pp. 948-949, 1962.

[2] I. Issemann and S. Green, "Activation of a member of the steroid hormone receptor superfamily by peroxisome proliferators," Nature, vol. 347, no. 6294, pp. 645-650, 1990.

[3] S. L. Primo-Parmo, R. C. Sorenson, J. Teiber, and B. N. La Du, "The human serum paraoxonase/arylesterase gene (PON1) is one member of a multigene family," Genomics, vol. 33, no. 3, pp. 498-507, 1996.

[4] R. C. Sorenson, S. L. Primo-Parmo, S. A. Camper, and B. N. $\mathrm{La} \mathrm{Du}$, "The genetic mapping and gene structure of mouse paraoxonase/arylesterase," Genomics, vol. 30, no. 3, pp. 431438, 1995.

[5] L. C. Jaouad, C. de Guise, H. Berrougui et al., "Age-related decrease in high-density lipoproteins antioxidant activity is due to an alteration in the PON1's free sulfhydyl groups," Atherosclerosis, vol. 185, no. 1, pp. 191-200, 2006.

[6] I. Leviev, F. Negro, and R. W. James, "Two alleles of the human paraoxonase gene produce different amounts of mRNA: an explanation for differences in serum concentrations of paraoxonase associated with the (Leu-Met54) polymorphism," Arteriosclerosis, Thrombosis, and Vascular Biology, vol. 17, no. 11, pp. 2935-2939, 1997.

[7] F. Rodríguez-Sanabria, A. Rull, R. Beltrán-Debón et al., "Tissue distribution and expression of paraoxonases and chemokines in mouse: the ubiquitous and joint localisation suggest a systemic and coordinated role," Journal of Molecular Histology, vol. 41, no. 6, pp. 379-386, 2010. 
[8] C. J. Ng, D. J. Wadleigh, A. Gangopadhyay et al., "Paraoxonase2 is a ubiquitously expressed protein with antioxidant properties and is capable of preventing cell-mediated oxidative modification of low density lipoprotein," Journal of Biological Chemistry, vol. 276, no. 48, pp. 44444-44449, 2001.

[9] W. N. Aldridge, "Serum esterases. I. Two types of esterase (A and B) hydrolysing p-nitrophenyl acetate, propionate and butyrate, and a method for their determination," The Biochemical Journal, vol. 53, no. 1, pp. 110-117, 1953.

[10] W. N. Aldridge, "Serum esterases. II. An enzyme hydrolysing diethyl p-nitrophenyl phosphate (E600) and its identity with the A-esterase of mammalian sera," The Biochemical Journal, vol. 53, no. 1, pp. 117-124, 1953.

[11] T. L. Diepgen and M. Geldmacher von Mallinckrodt, "Interethnic differences in the detoxification of organophosphates: the human serum paraoxonase polymorphism," Archives of Toxicology, vol. 59, no. 9, pp. 154-158, 1986.

[12] C. E. Furlong, "Paraoxonases: an historical perspective," in The Paraoxonases: Their Role in Disease Development and Xenobiotic Metabolism, B. Mackness, M. Mackness, M. Aviram, and G. Paragh, Eds., pp. 3-31, Springer, Dordrecht, The Netherlands, 2008.

[13] H. Davies, R. J. Richter, M. Keifer, C. Broomfield, J. Sowalla, and C. E. Furlong, "The effect of the human serum paraoxonase polymorphism is reversed with diazoxon, soman and sarin," Nature Genetics, vol. 14, no. 3, pp. 334-336, 1996.

[14] H. W. Eckerson, J. Romson, C. Wyte, and B. N. La Du, “The human serum paraoxonase polymorphism: identification of phenotypes by their response to salts," American Journal of Human Genetics, vol. 35, no. 2, pp. 214-227, 1983.

[15] H. W. Eckerson, C. M. Wyte, and B. N. La Du, "The human serum paraoxonase/arylesterase polymorphism," American Journal of Human Genetics, vol. 35, no. 6, pp. 1126-1138, 1983.

[16] S. Adkins, K. Gan, M. Mody, and B. N. La Du, "Molecular basis for the polymorphic forms of human serum paraoxonase/arylesterase: glutamine or arginine at position 191, for the respective A or B allozymes," American Journal of Human Genetics, vol. 52, no. 3, pp. 598-608, 1993.

[17] M. C. Blatter Garin, R. W. James, P. Dussoix et al., "Paraoxonase polymorphism Met-Leu54 is associated with modified serum concentrations of the enzyme. A possible link between the paraoxonase gene and increased risk of cardiovascular disease in diabetes," Journal of Clinical Investigation, vol. 99, no. 1, pp. 62-66, 1997.

[18] M. I. Mackness, S. Arrol, and P. N. Durrington, "Paraoxonase prevents accumulation of lipoperoxides in low-density lipoprotein," FEBS Letters, vol. 286, no. 1-2, pp. 152-154, 1991.

[19] M. I. Mackness, S. Arrol, C. A. Abbott, and P. N. Durrington, "Protection of low-density lipoprotein against oxidative modification by high-density lipoprotein associated paraoxonase," Atherosclerosis, vol. 104, no. 1-2, pp. 129-135, 1993.

[20] M. Navab, J. A. Berliner, A. D. Watson et al., "The Yin and Yang of oxidation in the development of the fatty streak: a review based on the 1994 George Lyman Duff memorial lecture," Arteriosclerosis, Thrombosis, and Vascular Biology, vol. 16, no. 7, pp. 831-842, 1996.

[21] M. Aviram, M. Rosenblat, C. L. Bisgaier, R. S. Newton, S. L. Primo-Parmo, and B. N. La Du, "Paraoxonase inhibits highdensity lipoprotein oxidation and preserves its functions: a possible peroxidative role for paraoxonase," Journal of Clinical Investigation, vol. 101, no. 8, pp. 1581-1590, 1998.

[22] M. Aviram, S. Billecke, R. Sorenson et al., "Paraoxonase active site required for protection against LDL oxidation involves its free sulfhydryl group and is different from that required for its arylesterase/paraoxonase activities: selective action of human paraoxonase allozymes Q and R," Arteriosclerosis, Thrombosis, and Vascular Biology, vol. 18, no. 10, pp. 1617-1624, 1998.

[23] M. I. Mackness, P. N. Durrington, and B. Mackness, "How high-density lipoprotein protects against the effects of lipid peroxidation," Current Opinion in Lipidology, vol. 11, no. 4, pp. 383-388, 2000.

[24] Z. Ahmed, A. Ravandi, G. F. Maguire et al., "Apolipoprotein A-I promotes the formation of phosphatidylcholine core aldehydes that are hydrolyzed by paraoxonase (PON-1) during high density lipoprotein oxidation with a peroxvnitrite donor," Journal of Biological Chemistry, vol. 276, no. 27, pp. 2447324481, 2001.

[25] P. Sangvanich, B. Mackness, S. J. Gaskell, P. Durrington, and M. Mackness, "The effect of high-density lipoproteins on the formation of lipid/protein conjugates during in vitro oxidation of low-density lipoprotein," Biochemical and Biophysical Research Communications, vol. 300, no. 2, pp. 501-506, 2003.

[26] A. Mertens, P. Verhamme, J. K. Bielicki et al., "Increased low-density lipoprotein oxidation and impaired high-density lipoprotein antioxidant defense are associated with increased macrophage homing and atherosclerosis in dyslipidemic obese mice: LCAT gene transfer decreases atherosclerosis," Circulation, vol. 107, no. 12, pp. 1640-1646, 2003.

[27] D. M. Shih, L. Gu, Y. R. Xia et al., "Mice lacking serum paraoxonase are susceptible to organophosphate toxicity and atherosclerosis," Nature, vol. 394, no. 6690, pp. 284-287, 1998.

[28] D. M. Shih, Y. R. Xia, E. Miller et al., "Combined serum paraoxonase knockout/apolipoprotein E knockout mice exhibit increased lipoprotein oxidation and atherosclerosis," Journal of Biological Chemistry, vol. 275, no. 23, pp. $17527-17535,2000$.

[29] A. Tward, Y. R. Xia, X. P. Wang et al., "Decreased atherosclerotic lesion formation in human serum paraoxonase transgenic mice," Circulation, vol. 106, no. 4, pp. 484-490, 2002.

[30] M. N. Oda, J. K. Bielicki, T. T. Ho, T. Berger, E. M. Rubin, and T. M. Forte, "Paraoxonase 1 overexpression in mice and its effect on high-density lipoproteins," Biochemical and Biophysical Research Communications, vol. 290, no. 3, pp. 921927, 2002.

[31] M. Aviram, M. Rosenblat, S. Billecke et al., "Human serum paraoxonase (PON 1) is inactivated by oxidized low density lipoprotein and preserved by antioxidants," Free Radical Biology and Medicine, vol. 26, no. 7-8, pp. 892-904, 1999.

[32] O. Rozenberg and M. Aviram, "S-Glutathionylation regulates HDL-associated paraoxonase 1 (PON1) activity," Biochemical and Biophysical Research Communications, vol. 351, no. 2, pp. 492-498, 2006.

[33] H. Jakubowski, "Calcium-dependent human serum homocysteine thiolactone hydrolase. A protective mechanism against protein N-homocysteinylation," Journal of Biological Chemistry, vol. 275, no. 6, pp. 3957-3962, 2000.

[34] J. F. Teiber, D. I. Draganov, and B. N. La Du, "Lactonase and lactonizing activities of human serum paraoxonase (PON1) and rabbit serum PON3," Biochemical Pharmacology, vol. 66, no. 6, pp. 887-896, 2003.

[35] K. Biggadike, R. M. Angell, C. M. Burgess et al., "Selective plasma hydrolysis of glucocorticoid $\gamma$-lactones and cyclic carbonates by the enzyme paraoxonase: an ideal plasma inactivation mechanism," Journal of Medicinal Chemistry, vol. 43, no. 1, pp. 19-21, 2000.

[36] B. N. La Du, M. Aviram, S. Billecke et al., "On the physiological role(s) of the paraoxonases," Chemico-Biological Interactions, vol. 119-120, pp. 379-388, 1999. 
[37] M. Harel, A. Aharoni, L. Gaidukov et al., "Structure and evolution of the serum paraoxonase family of detoxifying and anti-atherosclerotic enzymes," Nature Structural and Molecular Biology, vol. 11, no. 5, pp. 412-419, 2004.

[38] O. Khersonsky, C. Roodveldt, and D. S. Tawfik, "Enzyme promiscuity: evolutionary and mechanistic aspects," Current Opinion in Chemical Biology, vol. 10, no. 5, pp. 498-508, 2006.

[39] R. A. Jensen, "Enzyme recruitment in evolution of new function," Annual Review of Microbiology, vol. 30, pp. 409-425, 1976.

[40] U. T. Bornscheuer and R. J. Kazlauskas, "Catalytic promiscuity in biocatalysis: using old enzymes to form new bonds and follow new pathways," Angewandte Chemie, vol. 43, no. 45, pp. 6032-6040, 2004.

[41] S. D. Copley, "Enzymes with extra talents: moonlighting functions and catalytic promiscuity," Current Opinion in Chemical Biology, vol. 7, no. 2, pp. 265-272, 2003.

[42] R. J. Kazlauskas, "Enhancing catalytic promiscuity for biocatalysis," Current Opinion in Chemical Biology, vol. 9, no. 2, pp. 195-201, 2005.

[43] P. J. O'Brien and D. Herschlag, "Catalytic promiscuity and the evolution of new enzymatic activities," Chemistry and Biology, vol. 6, no. 4, pp. R91-R105, 1999.

[44] A. Aharoni, G. Amitai, K. Bernath, S. Magdassi, and D. S. Tawfik, "High-throughput screening of enzyme libraries: thiolactonases evolved by fluorescence-activated sorting of single cells in emulsion compartments," Chemistry and Biology, vol. 12, no. 12, pp. 1281-1289, 2005.

[45] A. Aharoni, L. Gaidukov, O. Khersonsky, S. M. Gould, C. Roodveldt, and D. S. Tawfik, "The "evolvability" of promiscuous protein functions," Nature Genetics, vol. 37, no. 1, pp. 73-76, 2005.

[46] A. Aharoni, L. Gaidukov, S. Yagur, L. Toker, I. Silman, and D. S. Tawfik, "Directed evolution of mammalian paraoxonases PON1 and PON3 for bacterial expression and catalytic specialization," Proceedings of the National Academy of Sciences of the United States of America, vol. 101, no. 2, pp. 482-487, 2004.

[47] O. Khersonsky and D. S. Tawfik, "Structure-reactivity studies of serum paraoxonase PON1 suggest that its native activity is lactonase," Biochemistry, vol. 44, no. 16, pp. 6371-6382, 2005.

[48] H. Tavori, S. Khatib, M. Aviram, and J. Vaya, "Characterization of the PON1 active site using modeling simulation, in relation to PON1 lactonase activity," Bioorganic and Medicinal Chemistry, vol. 16, no. 15, pp. 7504-7509, 2008.

[49] O. Khersonsky and D. S. Tawfik, "The histidine 115-histidine 134 dyad mediates the lactonase activity of mammalian serum paraoxonases," Journal of Biological Chemistry, vol. 281, no. 11, pp. 7649-7656, 2006.

[50] M. Rosenblat, L. Gaidukov, O. Khersonsky et al., "The catalytic histidine dyad of high density lipoprotein-associated serum paraoxonase-1 (PON1) is essential for PON1-mediated inhibition of low density lipoprotein oxidation and stimulation of macrophage cholesterol efflux," Journal of Biological Chemistry, vol. 281, no. 11, pp. 7657-7665, 2006.

[51] N. Bourquard, D. M. Shih, and C. J. Ng et al, "The role of PON2 and PON3 in atherosclerosis and related trait," in The Paraoxonases: Their Role in Disease Development and Xenobiotic Metabolism, B. Mackness, M. Mackness, M. Aviram, and G. Paragh, Eds., pp. 103-128, Springer, Dordrecht, The Netherlands, 2008.

[52] S. T. Reddy, D. J. Wadleigh, V. Grijalva et al., "Human paraoxonase-3 is an HDL-associated enzyme with biological activity similar to paraoxonase-1 protein but is not regulated by oxidized lipids," Arteriosclerosis, Thrombosis, and Vascular Biology, vol. 21, no. 4, pp. 542-547, 2001.

[53] D. Draganov, P. L. Stetson, C. E. Watson, S. Billecke, and B. N. La Du, "Rabbit serum paraoxonase 3 (PON3) is a high density lipoprotein-associated lactonase and protects low density lipoprotein against oxidation," Journal of Biological Chemistry, vol. 275, no. 43, pp. 33435-33442, 2000.

[54] G. Paragh, M. Harangi, and I. Seres, "Effect of lipid lowering medications in PON1," in The Paraoxonases: Their Role in Disease Development and Xenobiotic Metabolism, B. Mackness, M. Mackness, M. Aviram, and G. Paragh, Eds., pp. 251-266, Springer, Dordrecht, The Netherlands, 2008.

[55] P. N. Durrington, M. I. Mackness, D. Bhatnagar et al., "Effects of two different fibric acid derivatives on lipoproteins, cholesteryl ester transfer, fibrinogen, plasminogen activator inhibitor and paraoxonase activity in type IIb hyperlipoproteinaemia," Atherosclerosis, vol. 138, no. 1, pp. 217-225, 1998.

[56] V. Tsimihodimos, A. Kakafika, A. P. Tambaki et al., "Fenofibrate induces HDL-associated PAF-AH but attenuates enzyme activity associated with apoB-containing lipoproteins," Journal of Lipid Research, vol. 44, no. 5, pp. 927-934, 2003.

[57] G. Paragh, I. Seres, M. Harangi et al., "The effect of micronised fenofibrate on paraoxonase activity in patients with coronary heart disease," Diabetes and Metabolism, vol. 29, no. 6, pp. 613-618, 2003.

[58] G. Paragh, I. Seres, M. Harangi et al., "Ciprofibrate increases paraoxonase activity in patients with metabolic syndrome," British Journal of Clinical Pharmacology, vol. 61, no. 6, pp. 694701, 2006.

[59] Z. Ackerman, M. Oron-Herman, T. Rosenthal et al., "Effects of amlodipine, captopril, and bezafibrate on oxidative milieu in rats with fatty liver," Digestive Diseases and Sciences, vol. 53, no. 3, pp. 777-784, 2008.

[60] W. Phuntuwate, C. Suthisisang, B. Koanantakul, P. Chaloeiphap, B. Mackness, and M. Mackness, "Effect of fenofibrate therapy on paraoxonasel status in patients with low HDL-C levels," Atherosclerosis, vol. 196, no. 1, pp. 122-128, 2008.

[61] C. Gouédard, N. Koum-Besson, R. Barouki, and Y. Morel, "Opposite regulation of the human paraoxonase-1 gene PON1 by fenofibrate and statins," Molecular Pharmacology, vol. 63, no. 4, pp. 945-956, 2003.

[62] P. Raskin, E. B. Rappaport, S. T. Cole, Y. Yan, R. Patwardhan, and M. I. Freed, "Rosiglitazone short-term monotherapy lowers fasting and post-prandial glucose in patients with Type II diabetes," Diabetologia, vol. 43, no. 3, pp. 278-284, 2000.

[63] J. P. van Wijk, E. J. de Koning, M. C. Cabezas, and T. J. Rabelink, "Rosiglitazone improves postprandial triglyceride and free fatty acid metabolism in type 2 diabetes," Diabetes Care, vol. 28, no. 4, pp. 844-849, 2005.

[64] B. Chappuis, M. Braun, C. Stettler et al., "Differential effect of pioglitazone (PGZ) and rosiglitazone (RGZ) on postprandial glucose and lipid metabolism in patients with type 2 diabetes mellitus: a prospective, randomized crossover study," Diabetes/Metabolism Research and Reviews, vol. 23, no. 5, pp. 392-399, 2007.

[65] J. van Wijk, B. Coll, M. C. Cabezas et al., "Rosiglitazone modulates fasting and post-prandial paraoxonase 1 activity in type 2 diabetic patients," Clinical and Experimental Pharmacology and Physiology, vol. 33, no. 12, pp. 1134-1137, 2006.

[66] K. Mulligan, Y. Yang, D. A. Wininger et al., "Effects of metformin and rosiglitazone in HIV-infected patients with hyperinsulinemia and elevated waist/hip ratio," AIDS, vol. 21, no. 1, pp. 47-57, 2007. 
[67] B. Coll, J. P. H. van Wijk, S. Parra et al., "Effects of rosiglitazone and metformin on postprandial paraoxonase-1 and monocyte chemoattractant protein-1 in human immunodeficiency virus-infected patients with lipodystrophy," European Journal of Pharmacology, vol. 544, no. 1-3, pp. 104-110, 2006.

[68] J. A. Menendez, S. Cufí, C. Oliveras-Ferraros, L. Vellon, J. Joven, and A. Vazquez-Martin, "Gerosuppressant metformin: less is more," Aging, vol. 3, no. 4, pp. 348-362, 2011.

[69] M. Tomás, M. Sentí, F. García-Faria et al., "Effect of simvastatin therapy on paraoxonase activity and related lipoproteins in familial hypercholesterolemic patients," Arteriosclerosis, Thrombosis, and Vascular Biology, vol. 20, no. 9, pp. 2113$2119,2000$.

[70] Y. Shen, H. Wu, C. Wang et al., "Simvastatin attenuates cardiopulmonary bypass-induced myocardial inflammatory injury in rats by activating peroxisome proliferator-activated receptor $\gamma$," European Journal of Pharmacology, vol. 649, no. 1-3, pp. 255-262, 2010.

[71] J. A. Wang, W. A. Chen, Y. Wang et al., "Statins exert differential effects on angiotensin II-induced atherosclerosis, but no benefit for abdominal aortic aneurysms," Atherosclerosis, vol. 217, no. 1, pp. 90-96, 2011.

[72] M. Harangi, I. Seres, Z. Varga et al., "Atorvastatin effect on high-density lipoprotein-associated paraoxonase activity and oxidative DNA damage," European Journal of Clinical Pharmacology, vol. 60, no. 10, pp. 685-691, 2004.

[73] A. Kassai, L. Illyés, H. Z. Mirdamadi et al., "The effect of atorvastatin therapy on lecithin: cholesterol acyltransferase, cholesteryl ester transfer protein and the antioxidant paraoxonase," Clinical Biochemistry, vol. 40, no. 1-2, pp. 1-5, 2007.

[74] I. M. Bolayirli, M. Aslan, H. Balci, T. Altug, M. Hacibekiroglu, and A. Seven, "Effects of atorvastatin therapy on hypercholesterolemic rabbits with respect to oxidative stress, nitric oxide pathway and homocysteine," Life Sciences, vol. 81, no. 2, pp. 121-127, 2007.

[75] S. C. Bergheanu, A. Van Tol, G. M. Dallinga-Thie et al., "Effect of rosuvastatin versus atorvastatin treatment on paraoxonase1 activity in men with established cardiovascular disease and a low HDL-cholesterol," Current Medical Research and Opinion, vol. 23, no. 9, pp. 2235-2240, 2007.

[76] H. Mirdamadi, F. Sztanek, Z. Derdak, I. Seres, M. Harangi, and G. Paragh, "The human paraoxonase-1 phenotype modifies the effect of statins on paraoxonase activity and lipid parameters," British Journal of Clinical Pharmacology, vol. 66, no. 3, pp. 366-374, 2008.

[77] M. Shiner, B. Fuhrman, and M. Aviram, "Macrophage paraoxonase 2 (PON2) expression is up-regulated by pomegranate juice phenolic anti-oxidants via PPAR $y$ and AP-1 pathway activation," Atherosclerosis, vol. 195, no. 2, pp. 313-321, 2007.

[78] J. Khateeb, A. Gantman, A. J. Kreitenberg, M. Aviram, and B. Fuhrman, "Paraoxonase 1 (PON1) expression in hepatocytes is upregulated by pomegranate polyphenols: a role for PPAR- $\gamma$ pathway," Atherosclerosis, vol. 208, no. 1, pp. 119-125, 2010.

[79] J. Marsillach, J. Camps, N. Ferré et al., "Paraoxonase-1 is related to inflammation, fibrosis and PPAR delta in experimental liver disease," BMC Gastroenterology, vol. 9, article 3, 2009.

[80] A. J. Lusis, “Atherosclerosis," Nature, vol. 407, no. 6801, pp. 233-241, 2000.

[81] R. Ross, "The pathogenesis of atherosclerosis: a perspective for the 1990s," Nature, vol. 362, no. 6423, pp. 801-809, 1993.

[82] B. Mackness, D. Hine, Y. Liu, M. Mastorikou, and M. Mackness, "Paraoxonase-1 inhibits oxidised LDL-induced MCP-1 production by endothelial cells," Biochemical and Biophysical Research Communications, vol. 318, no. 3, pp. 680-683, 2004.

[83] A. Rull, R. García, L. Fernández-Sender et al., "The role of combined assessment of defense against oxidative stress and inflammation in the evaluation of peripheral arterial disease," Current Molecular Medicine, vol. 11, no. 6, pp. 453-464, 2011.

[84] A. Rull, J. Camps, C. Alonso-Villaverde, and J. Joven, "Insulin resistance, inflammation, and obesity: role of monocyte chemoattractant protein-1 (orCCL2) in the regulation of metabolism," Mediators of Inflammation, vol. 2010, Article ID 326580, 2010.

[85] J. X. Rong, J. W. Berman, M. B. Taubman, and E. A. Fisher, "Lysophosphatidylcholine stimulates monocyte chemoattractant protein-1 gene expression in rat aortic smooth muscle cells," Arteriosclerosis, Thrombosis, and Vascular Biology, vol. 22, no. 10, pp. 1617-1623, 2002.

[86] A. Rull, R. Beltrán-Debón, G. Aragonès et al., "Expression of cytokine genes in the aorta is altered by the deficiency in MCP1: effect of a high-fat, high-cholesterol diet," Cytokine, vol. 50, no. 2, pp. 121-128, 2010.

[87] C. H. Hsing, W. Chou, J. J. Wang, H. W. Chen, and C. H. Yeh, "Propofol increases bone morphogenetic protein-7 and decreases oxidative stress in sepsis-induced acute kidney injury," Nephrology Dialysis Transplantation, vol. 26, no. 4, pp. 1162-1172, 2011.

[88] C. C. Chuang, K. Martínez, and G. Xie et al, "Quercetin is equally or more effective than resveratrol in attenuating tumor necrosis factor alpha-mediated inflammation and insulin resistance in primary human adipocytes," American Journal of Clinical Nutrition, vol. 92, pp. 1511-1521, 2010.

[89] D. Wang, A. Haile, and L. C. Jones, "Rosiglitazone-induced adipogenesis in a bone marrow mesenchymal stem cell linebiomed 2011," Biomedical Sciences Instrumentation, vol. 47, pp. 213-221, 2011.

[90] W. M. Wang, H. Chen, F. Zhong, Y. Lu, L. Han, and N. Chen, "Inhibitory effects of rosiglitazone on lipopolysaccharideinduced inflammation in a murine model and HK-2 cells," American Journal of Nephrology, vol. 34, no. 2, pp. 152-162, 2011.

[91] T. Matsumura, H. Kinoshita, N. Ishii et al., "Telmisartan exerts antiatherosclerotic effects by activating peroxisome proliferator-activated receptor- $\gamma$ in macrophages," Arteriosclerosis, Thrombosis, and Vascular Biology, vol. 31, no. 6, pp. 1268-1275, 2011.

[92] M. E. Marketou, J. E. Kontaraki, N. A. Tsakountakis et al., "Differential effect of telmisartan and amlodipine on monocyte chemoattractant protein-1 and peroxisome proliferatoractivated receptor-gamma gene expression in peripheral monocytes in patients with essential hypertension," American Journal of Cardiology, vol. 107, no. 1, pp. 59-63, 2011. 


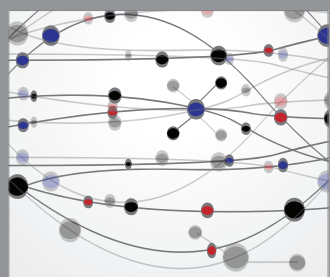

The Scientific World Journal
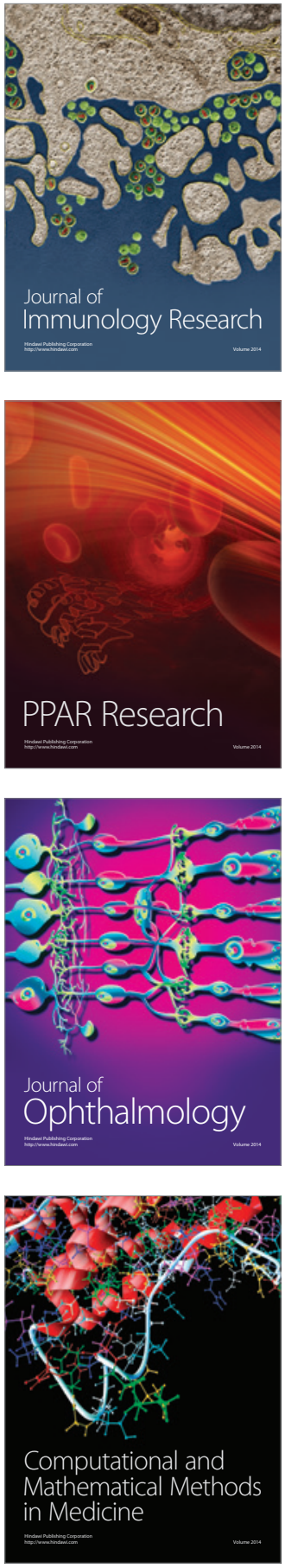

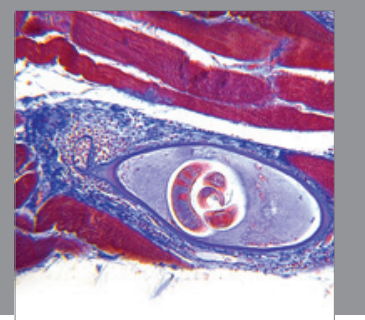

Gastroenterology

Research and Practice
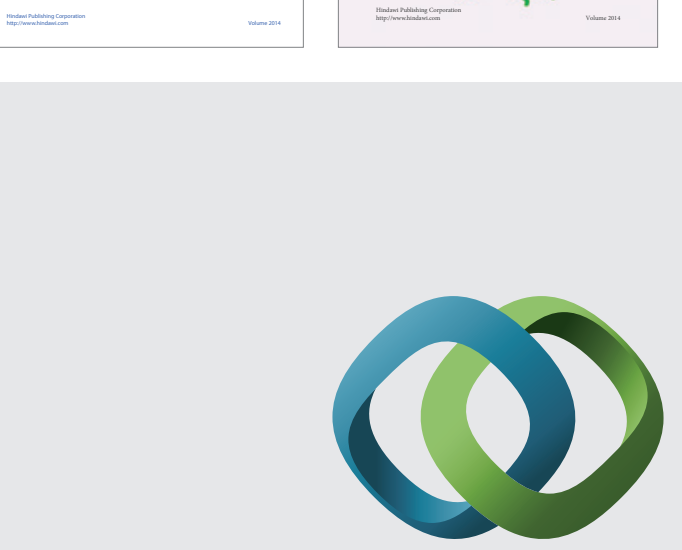

\section{Hindawi}

Submit your manuscripts at

http://www.hindawi.com
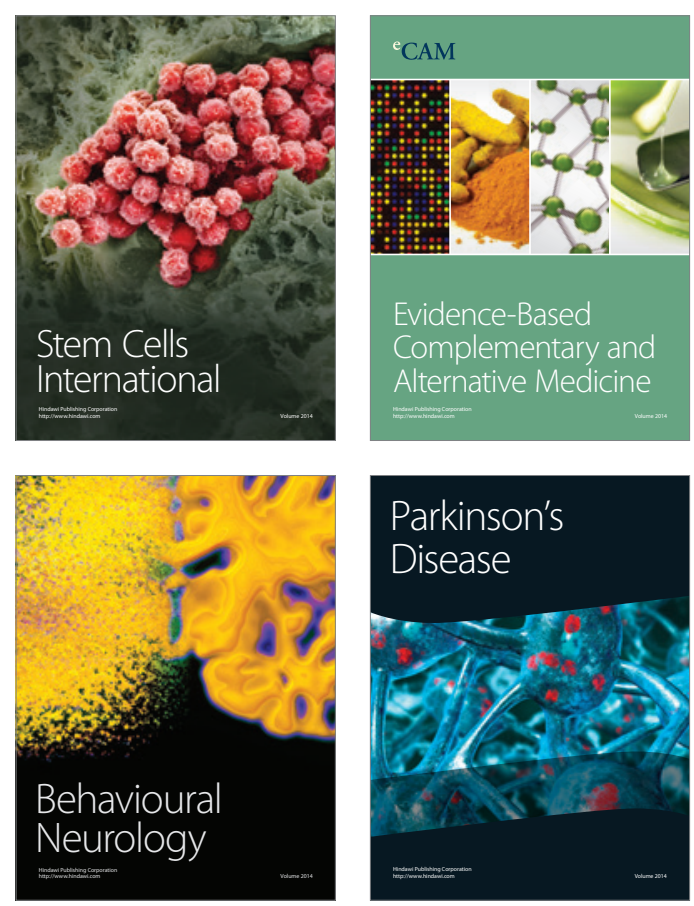

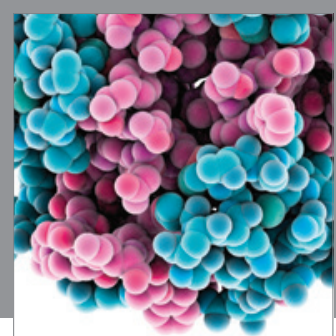

Journal of
Diabetes Research

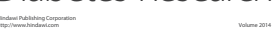

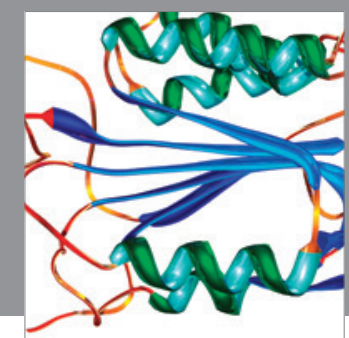

Disease Markers
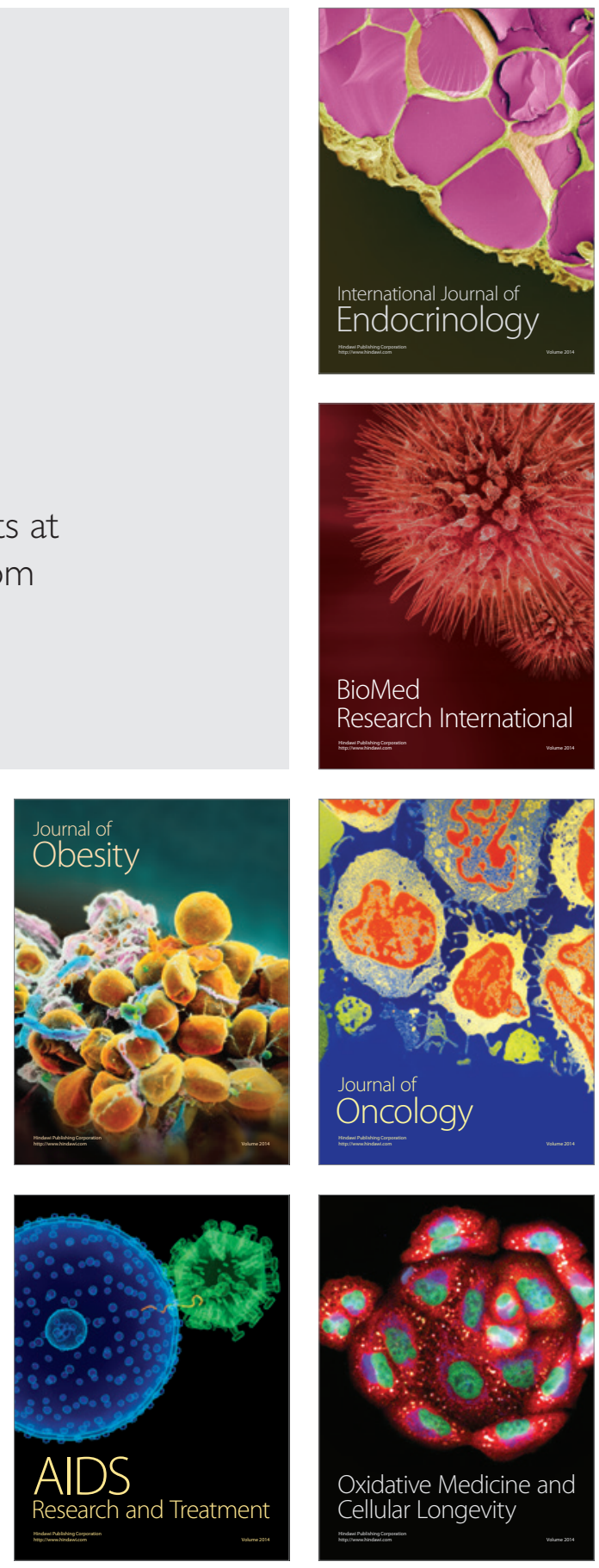